\title{
Changes in the sexual behaviour of young people: introduction
}

\author{
Marcantonio Caltabiano ${ }^{1 *}$, Maria Castiglioni ${ }^{2}$ and Alessandra De-Rose ${ }^{3}$
}

\author{
*Correspondence: caltabiano@ \\ unime.it \\ 'Dipartimento di Economia, \\ Università degli Studi di Messina, \\ Messina, Italy \\ Full list of author information is \\ available at the end of the article
}

Keywords: Sexuality, Youth, Contraception, Sexual orientation, Selfy

\section{Youth and sexuality}

If the sexual revolution of the 1960s unveiled changes in the sexual behaviour of young people that had silently begun in the previous decades, recent years have seen new and relevant changes, spurred by social media and the web propagating easy-going lifestyles, even in countries where such transformation proceeds at a slower pace (Barbagli, 2013; Bozon \& Kontula, 1998; Inchley et al., 2020; Treas, 2002; Wellings, Palmer, Machiyama, \& Slaymaker, 2019).

Today's young people are the grandchildren of men and women born in the 1940s and 1950s, who were the main actors in the sexual revolution. They are the "heirs of the sexual revolution"-as advanced by Billari, Caltabiano, and Dalla-Zuanna (2007) growing up in a more liberal and permissive family environment compared to their parents and grandparents.

The changes in sexual behaviour that characterised the last 50 years are related to a more general process of transformation, involving transition to adulthood, union formation and dissolution, and reproductive behaviour, which started in Northern and Western Europe between the 1960s and 1970s. This change slowly diffused elsewhere and was defined as the Second Demographic Transition (SDT) to distinguish it from the First Demographic Transition, which was the passage from a regime of high mortality and fertility to a low mortality and fertility one (Lesthaeghe \& Van de Kaa, 1986; Van de Kaa, 1987; for a recent global update, see Lesthaeghe, 2020).

These new features of contemporary societies have been interpreted mainly as consequences of a profound cultural change, with the emergence of new ideas and values that influence people's choices. Regarding sexual behaviour, two aspects are prominent: an increased emphasis placed on individual autonomy, including in sexual lifestyle, and the rejection of social control and rules (operated by the family, the church, the state, or other social institutions). Thus, premarital and extramarital sexual intercourse, extramarital fertility, and homosexual relationships have become more and more publicly disclosed and institutionalised. This radical change has also been powered by the

(c) The Author(s). 2020 Open Access This article is licensed under a Creative Commons Attribution 4.0 International License, which permits use, sharing, adaptation, distribution and reproduction in any medium or format, as long as you give appropriate credit to the original author(s) and the source, provide a link to the Creative Commons licence, and indicate if changes were made. The images or other third party material in this article are included in the article's Creative Commons licence, unless indicated otherwise in a credit line to the material. If material is not included in the article's Creative Commons licence and your intended use is not permitted by statutory regulation or exceeds the permitted use, you will need to obtain permission directly from the copyright holder. To view a copy of this licence, visit http://creativecommons.org/licenses/by/4.0/. 
contraceptive revolution, which was accompanied by the legalisation and subsequent diffusion of the contraceptive pill. This revolution has ultimately allowed for a separation of sexuality from reproduction, a more gender-equal role-set between partners, and generalised sexual freedom for women as well as men (Giddens, 1992; Goldscheider, Bernhardt, \& Lappegård, 2015; Gross, 2005).

An aspect of the SDT that is markedly related to changes in the sexual behaviour of young people is the de-structuration of life courses (Hagestad \& Dykstra, 2016; Liefbroer, 1999; Rindfuss, 1991). The passage to adulthood was traditionally subject to rigid and gender-differentiated normative regulations. In particular, the entrance into adult sexual life for women coincided with marriage or was experienced with the husband-to-be some months before the wedding (even if marriages in which the bride was pregnant were not rare). For men, there was usually much more freedom, and many had premarital intercourse with older women and/or prostitutes (Caltabiano \& Dalla-Zuanna, 2013). Moreover, the difference in age at marriage (higher for men than for women) allowed men 4 to 5 years of opportunity for premarital intercourse, compared to no more than 1 or 2 years for women (Billari et al., 2007). Finally, the postponement of sexual intercourse for young women was a means to limit non-marital pregnancies at a time when effective contraceptive methods were scarce or not available.

The SDT broke this rigid normative system, leading, on the one hand, to a fragmentation made of multiple and differentiated paths of passage to adulthood and on the other hand, to a convergence of behaviour among young men and women (Bertone, 2010).

Concerning the beginning of sexual life, the main changes are (1) sexual experiences can precede, for both men and women, not only marriage but also a stable couple relationship-giving place to an extended explorative phase where young people gradually discover and build their adult sexuality (Boislard, van de Bongardt, \& Blais, 2016; Kar, Choudhury, \& Singh, 2015; Vasilenko, Kreager, \& Lefkowitz, 2015); (2) first intercourse is experienced at a lower and lower age (Inchley et al., 2020; WHO, 2016): a remarkable percentage of young boys and especially girls experiencing it before the age of 15 in several developed countries, with an increased risk of sexually transmitted diseases and unwanted pregnancies; (3) age at first intercourse tends to converge between men and women, with men having intercourse with a woman of the same age, often in the context of a steady relationship (Caltabiano, 2005; Lewis et al., 2017).

Many individual characteristics and contextual factors influence young people's behaviour delaying, accelerating, and more generally shaping the early phases of youths' sexual lives (Billari et al., 2007; Caltabiano, Meggiolaro, \& Tocchioni, 2018). Among these determinants, parental family, school, and religion are especially influential, as found in different countries and cultures (Burdette, Hill, \& Myers, 2015; Cheshire, Kaestle, \& Miyazaki, 2019; Guilamo-Ramos et al., 2012; Landor, Simons, Simons, Brody, \& Gibbons, 2011; Pedersen, 2014; Poulin, 2011; Regnerus, 2005; Vivancos, Abubakar, Phillips-Howard, \& Hunter, 2013; White \& Warner, 2015; Widman, Choukas-Bradley, Noar, Nesi, \& Garrett, 2016). Young people who adhere to the rules set by these traditional actors of socialisation usually delay the sexual debut, take less risky behaviours, and follow a more "traditional" path of entry into adult life. Gender is another key factor: if the path of sexual debut is converging between males and females, this often has not meant true gender equality, as reflected by the pervasive diffusion of sexual 
harassment (Basile, D’Inverno, \& Wang, 2020; Elliott, Shui Ying Mok, \& Briere, 2004; Moore \& Mennicke, 2020), the differences in sexual practices, or the number of sexual partners (Lewis et al., 2017; Mercer et al., 2013). Indeed, sexual behaviour is still characterised by a double standard model in many Western societies (Allison \& Risman, 2013; Kreager, Staff, Gauthier, Lefkowitz, \& Feinberg, 2016; Sagebin Bordini \& Sperb, 2013).

Notwithstanding the importance of these behavioural changes and the need to deepen the driving factors, data on the sexuality of young people are scarce (Billari et al., 2007). If in some Western and Northern European countries there is a long tradition of research in this field (Bozon, 2003; Wellings et al., 2006) and in some others, this topic emerged in the early 1990s in response to the alarming spread of HIV, for many others, such as Southern and Eastern European countries, only fragmented studies (i.e. covering a limited time frame, specific issues, or particular groups of people) are available (Kontula \& Haavio-Mannila, 1995). Moreover, in several countries, sexuality is considered a too sensitive topic, for religious or cultural reasons, to be investigated by means of surveys or interviews (for example, in Muslim or Far Eastern countries). Consequently, contemporary research on youth sexuality, and sexuality in general, continues to be less thought through and detailed than the study of other aspects of family and reproductive behaviour, such as partnership dynamics and fertility. Finally, data on sexual behaviour collected in large surveys (see, for example, the HBSC-Health Behaviour in School-aged Children-survey on youth promoted by the European Regional Office of the WHO and many fertility and/or reproductive health surveys in developing countries) do not allow us to conduct meaningful analyses; after all, these surveys are designed to cover different topics, such as young people's risk behaviours or women's reproductive health.

In Italy, a recent survey called Selfy (Sexual and Emotional LiFe of Youths, waves 2000 and 2017) investigated affective and sexual attitudes and behaviours among university students by means of the accurate reconstruction of retrospective biographies (Minello et al., 2020). The novelty of Selfy inspired this Thematic Series and can be a stimulus for other countries where little is known about recent changes among young people.

On this backdrop, we perceived the opportunity to expand our knowledge on the sexual behaviour of young people, including specific aspects such as at-risk behaviours, contraception, virginity, sexually transmitted diseases, sexual satisfaction, sexual harassment, sexuality and peers, sexuality and age norms, and non-heterosexual orientation and behaviours, as well as problems related to data collection and methods of analysis. The purpose of the present paper collection is to provide new empirical evidence on this subject.

\section{The thematic series "Changes in the sexual behaviour of young people"}

This Thematic Series consists of thirteen articles that address the most important changes in young people's sexual behaviours. Many of them use the data of Selfy and concern different facets of sexual behaviour of Italian youth. They are accompanied by two articles concerning other European countries: the Netherlands-one of the countries where the sexual revolution began earlier-and Poland, an Eastern European country characterised by a strong role of religion in influencing the lives of young 
people. Finally, one last article concerns Indonesia, an Asian Muslim country where research on sexuality is particularly challenging as far as data and methods of analysis are concerned. Most of the papers follow a life course perspective, and all of them take gender dynamics into account.

The first paper, by Minello, Caltabiano, Dalla-Zuanna, and Vignoli (2020), provides general insights into the sexual behaviour and opinions of young Italians, comparing the results of the two Selfy surveys conducted in 2000 and 2017. Overall, the views and behaviours of males and females are getting closer. The authors observed a "feminisation" of male opinions and behaviour within couples, which is to say that men are more likely to experience first intercourse with a young woman of roughly the same age while in a stable relationship and are more faithful than in the past. Similarly, the authors found a "masculinisation" of female opinions and behaviour-for example, an increase in the number of occasional partners, a doubling of the acceptance of casual sex, and a net drop in virginity as a taboo. Important gender differences remain, however, especially concerning sexual double standards: young men and women are still subject to different rules guiding their sexual behaviour.

Migheli and Pronzato (2020) explicitly disentangled patterns of double standards, intended as standards of good behaviour that some people are expected to follow but others are not. They found that double standards persist among Italian university students, in that more males than females express their disapproval of a series of sexual behaviours when peers of either gender participate in those behaviours. They also found that the cultural context matters more than the family in shaping students' beliefs.

Double standards also influence the timing and context of sexual debut. From the same Italian university students' data, Carella, García-Pereiro, Pace, and Paterno (2020) showed that women tend to choose an older partner to have their first sexual experience with and are less likely than men to be involved in a first sexual relationship with a younger partner. Age at sexual debut tends to occur earlier in a relationship with an older partner. However, things are changing: between 2000 and 2017, the frequency of those who have sexual intercourse with partners of the same age has increased.

As a result of an increasingly precocious sexual debut, a reduction between the two Selfy surveys of both male and female students who reported not having had complete vaginal/penile intercourse at the time of the interview is observed. The theme of virginity has been deepened by Stranges and Vignoli (2020), who detected the salience of several demographic-, family-, interpersonal-, bodily-, and health-related factors associated with virginity status. They also showed that, although religiosity is still important to the sexual lives of Italian youths, its relevance is weakening over time.

Indeed, the Catholic religion plays an important role in shaping the sexual behaviour of young people in other European countries: based on comparable survey data on Polish university students (waves 2001 and 2013), Wróblewska (2020) showed that religiosity is a relevant differentiating factor for the risk of first intercourse before the age of eighteen in Poland. She also found that religiosity acts as a significant predictor of sexual abstinence only if a young person regards religion as particularly important; again, there are important gender differences, with young males transitioning to sex earlier than young females. As happens in Italy, these gender-specific differences appear to reduce with time. 
The sexual experience, and the related satisfaction, has been examined in the paper of Terzera, Rimoldi, and Barbiano di Belgiojoso (2020), who presented an analysis of the 2017 Selfy data. They showed that the sexual satisfaction of Italian university students is positively associated with the frequency of intercourse within a stable relationship. Furthermore, the results highlighted the essential role of all transitions, sexual and sentimental, in enhancing sexual satisfaction.

When dealing with young people's sexual behaviour, a crucial aspect to be addressed is its potential riskiness in terms of health, academic performance, or aggressive behaviour. These aspects have been detailed in the three papers that follow. Using the 2017 Selfy data, Pirani and Matera (2020) found that some risky sexual behaviours (i.e. reduced use of the condom, especially with casual partners, and sexual intercourse with unknown persons) are quite diffused among Italian young people and more among males than females. Moreover, they showed that some psychological characteristics, such as body satisfaction, sensation seeking, and self-esteem, are important drivers of these unsafe behaviours, especially among men. Lanari, Mangiavacchi, and Pasqualini (2020) estimated the effect of sexual activity during adolescence on the academic performance of high school students in Italy. Their results suggested a negative relationship between sexual activity and the grade obtained in the high school final examination. Finally, Ortensi and Farina (2020) dealt with the very delicate issue of sexual violence and found results that go beyond the "simple" abuse of women by men: foreign students and sexual minorities are at a higher risk of sexual violence victimisation compared to peer Italian students and heterosexual ones.

A systematic comparison between the affective and sexual behaviours of Italian native students and those with a migratory background was offered by Gabrielli, Paterno, and Strozza (2020). Their results showed that male students not born in Italy have a greater inclination for liberal attitudes towards sex than their native counterparts, while there are no notable differences between foreign-born and native women. Moreover, the association between sex-related behaviours and risky lifestyles (such as alcohol drinking, drug taking, or fast driving) shows no difference by migratory status.

An important protective role against an adolescent's risky behaviours is played by the family of origin. Namely, parental involvement in sex education and the quality of parent-child communication about romantic feelings appear to have a protective effect on adolescent sexual behaviours. Pasqualini and De-Rose (2020) explored this topic with the Selfy data. They found that boys are generally less likely to talk to parents than girls and that those who have grown up with at least one older, same-gender sibling maintain a lower level of talk with parents about romantic sentiments, sexual matters, and contraception.

The prevention of unintended pregnancy through effective contraception is pivotal for adolescents' and young adults' well-being. This topic is explored by Marra, Meijer, and de Graaf (2020) with reference to a high-contraceptive country, the Netherlands. They assessed trends in the contraceptive methods used by young women aged between 12 and 25 years and found that the proportion of young women using SARC (short-acting reversible contraceptive) is decreasing, while LARC (long-acting reversible contraceptive) use increased remarkably between 2005 and 2017. These trends varied by religious groups and educational level, emphasising the potential for tailored preventative measures for these groups. 
For the final paper, we travelled to South Asia to address another important topic for this Thematic Series, which is the issue of data collection and methods of analysis. O'Donnell, Utomo, and McDonald (2020) explored the under-reporting of the prevalence of premarital sex amongst young adults in Greater Jakarta due to social taboos and stigmas about sexuality. By using the 2010 Greater Jakarta Transition to Adulthood Survey (GJTAS), they estimated evidence of under-reported premarital pregnancies based on discrepancies reported in the timing of marriage, first birth, first sexual intercourse, and sexual activities. They also showed how survival and life table analyses can be applied to identify individual, societal, and cultural predictors of premarital sex and its (under)reporting.

\section{Conclusions}

The articles presented in this Thematic Series not only provide a timely and vivid overview of the main transformations of young people's sexual behaviour, but also propose novel facets and approaches which, although largely based on data relating to university students in Italy, allow for more general reflections on the young people's universe.

First, gender differences appear as a prominent issue. Men and women are becoming more and more similar: in Italy, as well as in Poland, age at first sexual intercourse is decreasing for both genders, and the gap between boys and girls is closing. Many other behaviours are converging. For example, while young males increasingly experience their first sexual intercourse within a stable relationship, female students are approaching male students in that respect. Gender differences are also weakening with regard to the number of sexual partners and casual sexual intercourse. Sexual satisfaction, when experienced within couple relationships, is increasingly desired by both males and females. On the one hand, these results appear to dispel the prejudice that sexual satisfaction is an issue that does not concern women; on the other hand, they emphasise the importance, even for men, of being in an affective relationship as an essential condition of enhancing the quality of their own sexuality. These results show an important step in the sexual revolution: the achievement of pleasure is now a central aspect of sexual life not only for men but for women and more generally for the well-being of the couple (Leiblum, 2002).

Differences between genders persist; some specific behaviours (such as the number of sexual partners, casual sex, the use of pornography, and masturbation) remain more diffused among males. Besides, for men, a high frequency of intercourse is still considered a means for sexual satisfaction and, perhaps, proof of a "good performance". Most importantly, culturally rooted differences in opinions regarding sex and, above all, the double standards persist even among young people.

Second, the (changing) relationship of students with their parents also appears as a central issue, especially in a context characterised by strong intergenerational ties and the late exit from the parental family, such as in Italy. On the one hand, the influence of parents in shaping the opinions of their children is not as strong as in the past, at least regarding the differences in the sexual behaviours of males and females; on the other hand, the level of exchanges on emotional relationships and on the use of contraception is increasing within the family, both with mothers and fathers-even after a divorce-and with siblings (see also the comparative research in Madkour, Farhat, Halpern, Gabhainn, \& Godeau, 2012). 
Third, the old-fashioned link between religion and the sexual behaviours of young people is still topical. This Thematic Series offers interesting insights for those contexts strongly characterised by the Catholic religion. Although adherence to (Catholic) religion still plays a protective role on the age of first sexual intercourse-stronger in Poland than in Italy - in both countries its importance is decreasing, and it is limited to young people who manifest an active adhesion to religion. Overall, we are observing a convergence of behaviours between religious and non-religious persons, a process very similar to that observed for other aspects of the SDT, such as the spread of cohabitation, out of wedlock births, and divorces (Goldscheider, 2006; Lesthaeghe \& Surkyn, 1988; Vignoli \& Salvini, 2014; Westoff \& Jones, 1979).

\section{Policy implications}

Although no article claims to demonstrate causal links, much of the research presented here offers food for thought and proposals for policy interventions aimed at preventing the dangerous consequences and discomfort linked to sexuality, which are absolutely topical even among the "heirs of the sexual revolution".

In drawing preventative measures tailored to young people important aspects should be considered, such as the differences according to the level of education, adherence to religion, place of birth, the cultural and economic milieu in which one lives, and, above all, gender differences. The topics which are usually included in the standard sex education programmes (such as anatomy and reproductive health, information about contraception, childbirth, and sexually transmitted infections, including HIV) cannot be taken for granted. Selfy data show, for example, that many young people in Italy underestimate the risks associated with casual relationships, with sex with unknown partners, or with the lack of dialogue between partners on contraception. The Dutch data not only show us greater awareness and diffusion of long-active reversible contraceptives but also remind us that strong surveillance is needed: moving towards greater use of effective contraception must not lower the attention towards new dangers, especially those related to sexually transmitted diseases. It is not enough to offer sex education programmes. Specific strategies dealing more broadly with young people that also take into account psychological and personality characteristics-namely body satisfaction, selfesteem, and sensation seeking - can be of strong support in the face of psychological distress among adolescents and their risky behaviours (Blashill \& Safren, 2015; Gillen, Lefkowitz, \& Shearer, 2006; Potard, Lancelot, \& Courtois, 2019).

This Thematic Series also pays attention to issues regarding the treatment and respect of minorities (namely by migratory background or sexual orientation). These issues should be included in young people's educational programmes as the basis of effective preventative actions against any forms of violence and discrimination.

An indispensable premise for any intervention is a correct knowledge of behaviours and opinions, which needs reliable and updated data sources. The Selfy project, despite the limitations of population selection, constitutes an opportunity, especially in light of its large sample size and the possibility to operate a straightforward comparison between the 2000 and 2017 waves. As the article on Greater Jakarta amply demonstrates, such a sensitive topic as sexual behaviour must be addressed with attention, competence, and respect of the different cultural contexts, and this requires proper data and adequate methods of analysis. 


\section{Acknowledgements \\ None}

\section{Authors' contributions}

M. Caltabiano edited "Youth and Sexuality", A. De Rose edited "The Thematic Series 'Changes in the sexual behaviour of young people"', and M. Castiglioni edited "Conclusions" and "Policy implications". The authors read and approved the final manuscript.

\section{Funding}

None

\section{Availability of data and materials}

No data has been used in this Editorial.

\section{Competing interests}

We declare no competing interests.

\section{Author details}

${ }^{1}$ Dipartimento di Economia, Università degli Studi di Messina, Messina, Italy. ${ }^{2}$ Dipartimento di Scienze Statistiche, Università degli Studi di Padova, Padua, Italy. ${ }^{3}$ Dipartimento di Metodi e Modelli per I'Economia, il Territorio e la Finanza, Sapienza Università di Roma, Rome, Italy.

Received: 3 November 2020 Accepted: 7 November 2020

Published online: 26 November 2020

\section{References}

Allison, R., \& Risman, B. J. (2013). A double standard for "hooking up": How far have we come toward gender equality? Social Science Research, 42(5), 1191-1206. https://doi.org/10.1016/j.ssresearch.2013.04.006.

Barbagli, M. (2013). Sotto lo stesso tetto (new edition). Bologna: II Mulino.

Basile, K. C., D'Inverno, A. S., \& Wang, J. (2020). National prevalence of sexual violence by a workplace-related perpetrator. American Journal of Preventive Medicine, 58(2), 216-223. https://doi.org/10.1016/j.amepre.2019.09.011.

Bertone, C. (2010). Sessualità maschili e femminili, tra convergenze e nuove asimmetrie. In M. Barbagli, G. Dalla-Zuanna, \& F. Garelli (Eds.), La sessualità degli italiani, (pp. 207-234). Bologna: II Mulino.

Billari, F. C., Caltabiano, M., \& Dalla-Zuanna, G. (Eds.) (2007). Sexual and affective behaviour of students. An international research, Serie Ricerche del Dipartimento di Scienze Statistiche dell'Università di Padova, 9. Padova: Cleup.

Blashill, A., \& Safren, S. (2015). Body dissatisfaction and condom use self-efficacy: A meta-analysis. Body Image, 12, 73-77.

Boislard, M. A., van de Bongardt, D., \& Blais, M. (2016). Sexuality (and lack thereof) in adolescence and early adulthood: A review of the literature. Behavioral Sciences (Basel, Switzerland), 6(1), 8. https://doi.org/10.3390/bs6010008.

Bozon, M. (2003). At what age do women and men have their first sexual intercourse? World comparisons and recent trends. Population and Societies, 391, 1-4.

Bozon, M., \& Kontula, O. (1998). Sexual initiation and gender in Europe. A cross-cultural analysis of trends in the twentieth century. In M. Hubert, N. Bajos, \& T. Sandfort (Eds.), Sexual behaviour and HIV/AIDS in Europe. Comparison of national survey. London: UCL Press.

Burdette, A., Hill, T., \& Myers, K. (2015). Understanding religious variations in sexuality and sexual health. In J. De Lamater, \& R. Plante (Eds.), Handbook of the sociology of sexualities, (pp. 349-370). Cham: Springer.

Caltabiano, M. (2005). The first romantic relationship of adolescents: A comparative analysis. Genus, LXI, 141-160.

Caltabiano, M., \& Dalla-Zuanna, G. (2013). A comparison of survey techniques on sensitive sexual behavior in Italy. Journal of Sex Research, 50, 537-547.

Caltabiano, M., Meggiolaro, S., \& Tocchioni, V. (2018). L'inizio della vita affettiva e sessuale: Tempi, determinanti e profili dei giovani. Florence: Paper presented at the First Selfy Workshop 17-18 September 2018.

Carella, M., García-Pereiro, T., Pace, R., \& Paterno, A. (2020). The "dating game": Age differences at first sex of college students in Italy. Genus, 76, 23. https://doi.org/10.1186/s41118-020-00087-2.

Cheshire, E., Kaestle, C. E., \& Miyazaki, Y. (2019). The influence of parent and parent-adolescent relationship characteristics on sexual trajectories into adulthood. Archives of Sexual Behavior, 48(3), 893-910.

Elliott, D., Shui Ying Mok, D., \& Briere, J. (2004). Adult sexual assault: Prevalence, symptomatology, and sex differences in the general population. Journal of Traumatic Stress, 17(3), 203-211 https://doi.org/10.1023/B:JOTS.0000029263.11104.23.

Gabrielli, G., Paterno, A., \& Strozza, S. (2020). Sexual behavioural differences and risk-taking differences among born-abroad and native university students in Italy. Genus, 76, 17. https://doi.org/10.1186/s41118-020-00088-1.

Giddens, A. (1992). The transformation of intimacy: Sexuality, love and eroticism in modern societies. Stanford: Stanford University Press.

Gillen, M., Lefkowitz, E., \& Shearer, C. (2006). Does body image play a role in risky sexual behavior and attitudes? Journal of Youth and Adolescence, 35, 243-255.

Goldscheider, C. (2006). Religion, family, and fertility: What do we know historically and comparatively? In R. Derosas, \& F. van Poppel (Eds.), Religion and the decline of fertility in the western world, (pp. 41-57). Dordrecht: Springer. https://doi.org/10. 1007/1-4020-5190-5 3

Goldscheider, F., Bernhardt, E., \& Lappegård, T. (2015). The gender revolution: A framework for understanding changing family and demographic behavior. Population and Development Review, 41, 207-239.

Gross, N. (2005). The detraditionalization of intimacy reconsidered. Sociological Theory, 23, 286-311.

Guilamo-Ramos, V., Bouris, A., Lee, J., McCarthy, K., Michael, S. L., Pitt-Barnes, S., \& Dittus, P. (2012). Paternal influence on adolescent sexual risk behaviors: A structured literature review. Pediatrics, 130, 1313-1325. 
Hagestad, G. O., \& Dykstra, P. A. (2016). Structuration of the life course: Some neglected aspects. In M. J. Shanahan, J. T. Mortimer, \& M. Kirkpatrick Johnson (Eds.), Handbook of the life course, (2nd ed., pp. 131-157). New York: Springer.

Inchley, J., Currie, D., Budisavljevic, S., Torsheim, T., Jåstad, A., Cosma, A., et al. (2020). Spotlight on adolescent health and wellbeing. Findings from the 2017/2018 health behaviour in school-aged children (HBSC) survey in Europe and Canada. In International report. Volume 1. Key findings. Copenhagen: WHO Regional Office for Europe.

Kar, S. K., Choudhury, A., \& Singh, A. P. (2015). Understanding normal development of adolescent sexuality: A bumpy ride. Journal of Human Reproductive Sciences, 8(2), 70-74. https://doi.org/10.4103/0974-1208.158594.

Kontula, O., \& Haavio-Mannila, E. (1995). Sexual pleasures: Enhancement of sex life in Finland 1971-1992. Dartmouth: Aldershot

Kreager, D. A., Staff, J., Gauthier, R., Lefkowitz, E. S., \& Feinberg, M. E. (2016). The double standard at sexual debut: Gender, sexual behavior and adolescent peer acceptance. Sex Roles, 75(7), 377-392.

Lanari, D., Mangiavacchi, L., \& Pasqualini, M. (2020). Adolescent sexual behaviour and academic performance of Italian students. Genus, 76, 21. https://doi.org/10.1186/s41118-020-00093-4.

Landor, A., Simons, L. G., Simons, R. L., Brody, G. H., \& Gibbons, F. X. (2011). The role of religiosity in the relationship between parents, peers, and adolescent risky sexual behavior. Journal of Youth and Adolescence, 40, 296-309.

Leiblum, S. R. (2002). Reconsidering gender differences in sexual desire: An update. Sexual and Relationship Therapy, 17(1), 5768. https://doi.org/10.1080/14681990220108027.

Lesthaeghe, R. (2020). The second demographic transition, 1986-2020: Sub-replacement fertility and rising cohabitation-A global update. Genus, 76(10). https://doi.org/10.1186/s41118-020-00077-4.

Lesthaeghe, R., \& Van de Kaa, D. J. (1986). Twee demografische transities. In Lesthaeghe, \& van de Kaa (Eds.), Groei of Krimp? (pp. 9-24). Deventer: Van Loghum Slaterus.

Lesthaeghe, R. J., \& Surkyn, J. (1988). Cultural dynamics and economic theories of fertility change. Population and Development Review, 14(1), 1-45. https://doi.org/10.2307/1972499.

Lewis, R., Tanton, C., Mercer, C. H., Mitchell, K. R., Palmer, M., Macdowall, W., \& Wellings, K. (2017). Heterosexual practices among young people in Britain: Evidence from three National Surveys of sexual attitudes and lifestyles. Journal of Adolescent Health, 61(6), 694-702. https://doi.org/10.1016/j.jadohealth.2017.07.004.

Liefbroer, A. C. (1999). From youth to adulthood: Understanding changing patterns of family formation from a life course perspective. In L. J. G. van Wissen, \& P. A. Dykstra (Eds.), Population issues. An interdisciplinary focus. New York: Kluwer Academic/Plenum Publishers.

Madkour, A. S., Farhat, T., Halpern, C. T., Gabhainn, S., \& Godeau, E. (2012). Parents' support and knowledge of their daughters' lives, and females' early sexual initiation in nine European countries. Perspectives on Sexual and Reproductive Health, 44(3), $167-175$.

Marra, E., Meijer, S., \& de Graaf, H. (2020). Changes in young women's contraceptive use in the Netherlands: Findings from three sex under the age of 25 surveys. Genus, 76, 7. https://doi.org/10.1186/s41118-020-00078-3.

Mercer, C. H., Tanton, C., Prah, P., Erens, B., Sonnenberg, P., Clifton, S., ... Johnson, A. M. (2013). Changes in sexual attitudes and lifestyles in Britain through the life course and over time: Findings from the National Surveys of sexual attitudes and lifestyles (Natsal). The Lancet, 382(9907), 1781-1794. https://doi.org/10.1016/S0140-6736(13)62035-8.

Migheli, M., \& Pronzato, C. (2020). Thinking as the others do: Persistence and conformity of sexual double standard among young Italians. Genus, 76, 25. https://doi.org/10.1186/s41118-020-00095-2.

Minello, A., Caltabiano, M., Dalla-Zuanna, G., \& Vignoli, D. (2020). Catching up! The sexual behaviour and opinions of Italian students (2000-2017). Genus, 76, 16. https://doi.org/10.1186/s41118-020-00085-4.

Moore, J., \& Mennicke, A. (2020). Empathy deficits and perceived permissive environments: Sexual harassment perpetration on college campuses. Journal of Sexual Aggression, 26(3), 372-384.

O'Donnell, J., Utomo, I. D., \& McDonald, P. (2020). Premarital sex and pregnancy in greater Jakarta. Genus, 76, 13. https://doi. org/10.1186/s41118-020-00081-8.

Ortensi, L. E., \& Farina, P. (2020). Sexual violence victimisation among university students in Italy: A gendered intersectional quantitative approach. Genus, 76, 30. https://doi.org/10.1186/s41118-020-00101-7.

Pasqualini, M., \& De-Rose, A. (2020). Parent-child communication about sex and romantic feelings: Does having older siblings make a difference? Genus, 76, 24. https://doi.org/10.1186/s41118-020-00097-0.

Pedersen, W. (2014). Forbidden fruit? A longitudinal study of christianity, sex and marriage. Journal of Sex Research, 51, 542550.

Pirani, E., \& Matera, C. (2020). Who is at risk? Gendered psychological correlates in Italian students' sexual risk profiles. Genus, 76, 11. https://doi.org/10.1186/s41118-020-00080-9.

Potard, C., Lancelot, C., \& Courtois, R. (2019). Examining relationships between sexual risk- Safety behaviors and physical selfconcept by gender: A cluster analytical approach. Emerging Adulthood, 7(1), 31-44.

Poulin, F. (2011). Individual, familial, friends-related and contextual predictors of early sexual intercourse. Journal of Adolescence, 34, 289-300

Regnerus, M. D. (2005). Talking about sex: Religion and patterns of parent-child communication about sex and contraception. The Sociological Quarterly, 46(1), 79-105.

Rindfuss, R. R. (1991). The young adult years: Diversity, structural change, and fertility. Demography, 28, 493-512

Sagebin Bordini, G., \& Sperb, T. M. (2013). Sexual double standard: A review of the literature between 2001 and 2010. Sexuality and Culture, 17, 686-704. https://doi.org/10.1007/s12119-012-9163-0.

Stranges, M., \& Vignoli, D. (2020). "Like a virgin". Correlates of virginity among Italian university students. Genus, 76, 12. https:// doi.org/10.1186/541118-020-00082-7.

Terzera, L., Rimoldi, S. M. L., \& Barbiano di Belgiojoso, E. (2020). Sexual satisfaction among Italian university students. Genus, 76 29. https://doi.org/10.1186/s41118-020-00096-1.

Treas, J. (2002). How cohorts, education, and ideology shaped a new sexual revolution on American attitudes toward nonmarital sex, 1972-1998. Sociological Perspectives, 45, 267-283.

Van de Kaa, D. J. (1987). Europe's second demographic transition. Population Bullettin, 42. Washington DC: Population Reference Bureau.

Vasilenko, S. A., Kreager, D. A., \& Lefkowitz, E. S. (2015). Gender, contraceptive attitudes, and condom use in adolescent romantic relationships: A dyadic approach. Journal of Research on Adolescence, 25, 51-62. 
Vignoli, D., \& Salvini, S. (2014). Religion and union formation in Italy: Catholic precepts, social pressure, and tradition. Demographic Research, 31(35), 1079-1106. https://doi.org/10.4054/DemRes.2014.31.35.

Vivancos, R., Abubakar, I., Phillips-Howard, P., \& Hunter, P. R. (2013). School-based sex education is associated with reduced risky sexual behaviour and sexually transmitted infections in young adults. Public Health, 127(1), 53-57.

Wellings, K., Collumbien, M., Slaymaker, M., Singh, S., Hodges, Z., Patel, D., \& Bajos, N. (2006). Sexual behaviour in context: A global perspective. The Lancet, 368, 1706-1728.

Wellings, K., Palmer, M. J., Machiyama, K., \& Slaymaker, E. (2019). Changes in, and factors associated with, frequency of sex in Britain: Evidence from three National Surveys of sexual attitudes and lifestyles (Natsal). British Medical Journal, 365(11525). https://doi.org/10.1136/bmj.l1525.

Westoff, C. F., \& Jones, E. F. (1979). The end of "Catholic" fertility. Demography, 16(2), 209-217.

White, C. N., \& Warner, L. A. (2015). Influence of family and school-level factors on age of sexual initiation. Journal of Adolescent Health, 56, 231-237.

WHO (2016). Growing up unequal: Gender and socioeconomic differences in young people's health and well-being: Health behavior in school-aged children (HBSC study). In International report from the 2013/2014 survey. Geneve: WHO.

Widman, L., Choukas-Bradley, S., Noar, S. M., Nesi, J., \& Garrett, K. (2016). Parent-adolescent sexual communication and adolescent safer sex behavior: A meta-analysis. JAMA Pediatrics, 170(1), 52-61.

Wróblewska, W. (2020). Religiosity differences in the transition to first intercourse before age 18 among polish students. Genus, 76, 14. https://doi.org/10.1186/s41118-020-00083-6.

\section{Publisher's Note}

Springer Nature remains neutral with regard to jurisdictional claims in published maps and institutional affiliations.

Submit your manuscript to a SpringerOpen ${ }^{\circ}$ journal and benefit from:

- Convenient online submission

- Rigorous peer review

- Open access: articles freely available online

High visibility within the field

- Retaining the copyright to your article

Submit your next manuscript at $\boldsymbol{\nabla}$ springeropen.com 